\title{
Evidence for natural molecular hydrogen seepage associated with Carolina bays (surficial, ovoid depressions on the Atlantic Coastal Plain, Province of the USA)
}

Viacheslav Zgonnik ${ }^{1,4^{*}}$, Valérie Beaumont ${ }^{1}$, Eric Deville ${ }^{1}$, Nikolay Larin ${ }^{2}$, Daniel Pillot ${ }^{1}$ and Kathleen M. Farrell ${ }^{3}$

\begin{abstract}
A study of soil gases was made in North Carolina (USA) in and around morphological depressions called "Carolina bays." This type of depression is observed over the Atlantic coastal plains of the USA, but their origin remains debated. Significant concentrations of molecular hydrogen $\left(\mathrm{H}_{2}\right)$ were detected, notably around the bays. These measurements suggest that Carolina bays are the surficial expression of fluid flow pathways for hydrogen gas moving from depth to the surface. The potential mechanisms of $\mathrm{H}_{2}$ production and transport and the geological controls on the fluid migration pathways are discussed, with reference to the hypothesis that Carolina bays are the result of local collapses caused by the alteration of rock along the deep pathways of $\mathrm{H}_{2}$ migrating towards the surface. The present $\mathrm{H}_{2}$ seepages are comparable to those in similar structures previously observed in the East European craton.
\end{abstract}

Keywords: Hydrogen; Seepage; Carolina bays

\section{Background}

Carolina bays are surficial, consistently oriented, ovalshaped depressions that occur widely across the southeastern Atlantic Coastal Plain, Province of eastern North America (Brooks et al. 2010). They are well defined on satellite images (Figs. 2, 3, and 4) and densely cover parts of the Coastal Plain in North Carolina (NC) and South Carolina (SC). They vary in size, ranging from $\sim 100 \mathrm{~m}$ to $8 \mathrm{~km}$ in diameter (Lake Waccamaw, NC, USA). Slightly elevated rims $(\sim 1-3 \mathrm{~m})$, commonly consisting of sand, surround these features. Although some bays have continuous elevated rims, the rims do not usually completely encircle the bays but often form a crescent. The long axes of these elliptical features are preferentially oriented NW-SE (Figs. 1, 2, 3, and 4). Bays of various sizes may overlap, and small bays are frequently present

\footnotetext{
* Correspondence: Zgonnik@UAHE.net.ua

'IFP Energies Nouvelles, 1 et 4 avenue de Bois Préau, 92852 Rueil-Malmaison Cedex, France

${ }^{4}$ Present address: Natural Hydrogen Energy Ltd, 819-35th Ave., Greeley, CO 80634, USA

Full list of author information is available at the end of the article
}

inside larger bays (Fig. 2). In areas undisturbed by anthropogenic activities, these bays can include densely vegetated wetlands or open water lakes. These features were originally called "bays" because of the bay trees that inhabit these wet depressions or pocosins. Now, the term "bay" indicates a wet oval-shaped depression. Locally, these features are also called cypress domes, Grady ponds, citronelle ponds, wet prairies, sandhill ponds, etc. (Folkerts 1997). In anthropogenically modified areas, the bays are commonly drained and cleared for agriculture or other purposes. Even when modified, most of the bays are still easily discernable in satellite and Light Detection and Ranging (LiDAR) images because of their characteristic morphology and relief and the soil bleaching on their rims. Hundreds of thousands of bays occur along the Atlantic Coastal Plain from New Jersey to Florida (Prouty 1952), and in NC, the bays cover as much as $65 \%$ of the land surface of the Coastal Plain (Prouty 1952). Eyton and Parkhurst (1975) summarized the physical characteristics of Carolina bays.

The origin of Carolina bays is still unclear. Many theories have been proposed to explain their formation, 


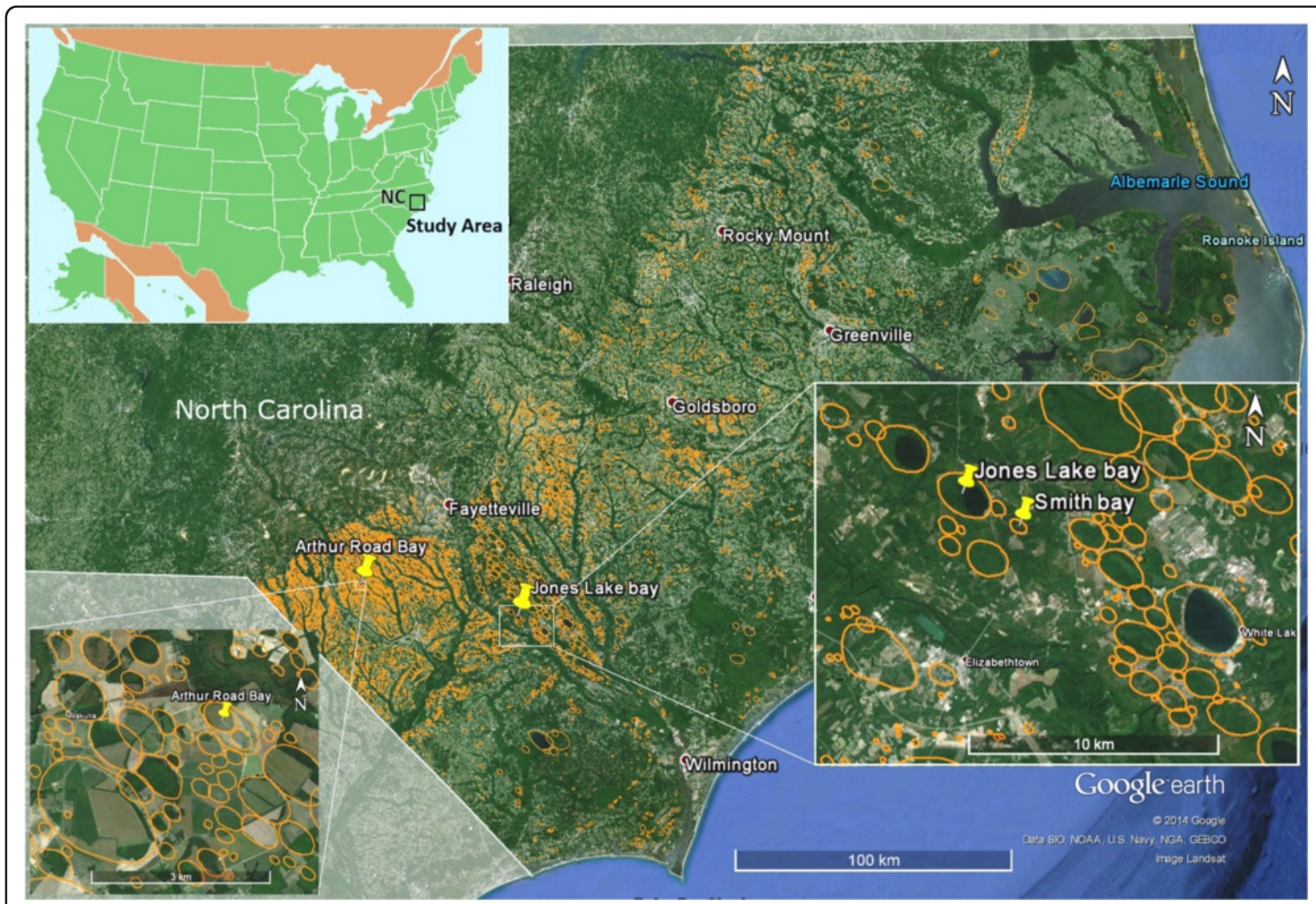

Fig. 1 Location of the study area. NC North Carolina. Carolina bays are outlined by orange polygons. This and all other satellite images in this article were downloaded from Google Earth and Google Earth Pro

including meteorite impact, comet impact, wind action, water table fluctuations, solution phenomena, and even fish nests (Ross 1987), but no general consensus has yet been reached.

In the present study, we examined the chemical compositions of the gases from the soils in selected Carolina bays and their vicinities to investigate the contents of $\mathrm{H}_{2}$ and other reduced gases. Our aim was to compare the bays with similar geomorphological features recently described in the East European craton (EEC) in Russia, which were shown to emit $\mathrm{H}_{2}$ gas in an area where the occurrence of $\mathrm{H}_{2}$ at depth (several hundred meters) has been confirmed in boreholes (Larin et al. 2014). A variety of mechanisms can produce $\mathrm{H}_{2}$, and there may be a causal link between these $\mathrm{H}_{2}$ emissions and the formation of these structures. The possible relationships between the $\mathrm{H}_{2}$ seepages and the observed geomorphological features were investigated.

\section{Geological framework}

The Atlantic Coastal Plain, Province of eastern North America, is the emergent part of a platform on a passive continental margin and is currently characterized by incised valleys that separate flat interfluves (Farrell et al. 2013). The continental shelf is underlain by a seaward-thickening wedge of sediment that thins westward to a feather edge along its boundary with the crystalline bedrock. This clastic wedge attains a maximum thickness of $3009 \mathrm{~m}$ ( $9854 \mathrm{ft}$ ) on land at Cape Hatteras (Lawrence and Hoffman 1993) and includes deposits of Cretaceous to Quaternary age (Brown et al. 1972). The sediment composition and recurring sedimentary facies on the NC Coastal Plain have been summarized by Farrell et al. (2012, 2013).

The NC Coastal Plain is predominantly a relict PlioPleistocene landscape, characterized by a series of progressively younger scarps, or paleoshorelines, and intervening terraces that step down in elevation and age towards the coast and towards the river incisions (see Fig. 1 in Farrell et al. 2013 and Figs. 1, 2, 3, and 4 in Abbott et al. 2011), forming a stair-step topography. Over the past $5 \mathrm{Ma}$, glacio-eustatic changes in sea level drove the transgressive-regressive cycles that sculpted this landscape. The surficial deposits that underlie the relict landscape include a complex assemblage of marine, barrier island, estuarine, fluvial, and other coastal plain deposits, which are predominantly Pliocene, Pleistocene, and Holocene in age. Abbott et al. (2011) summarized the surficial geology and 

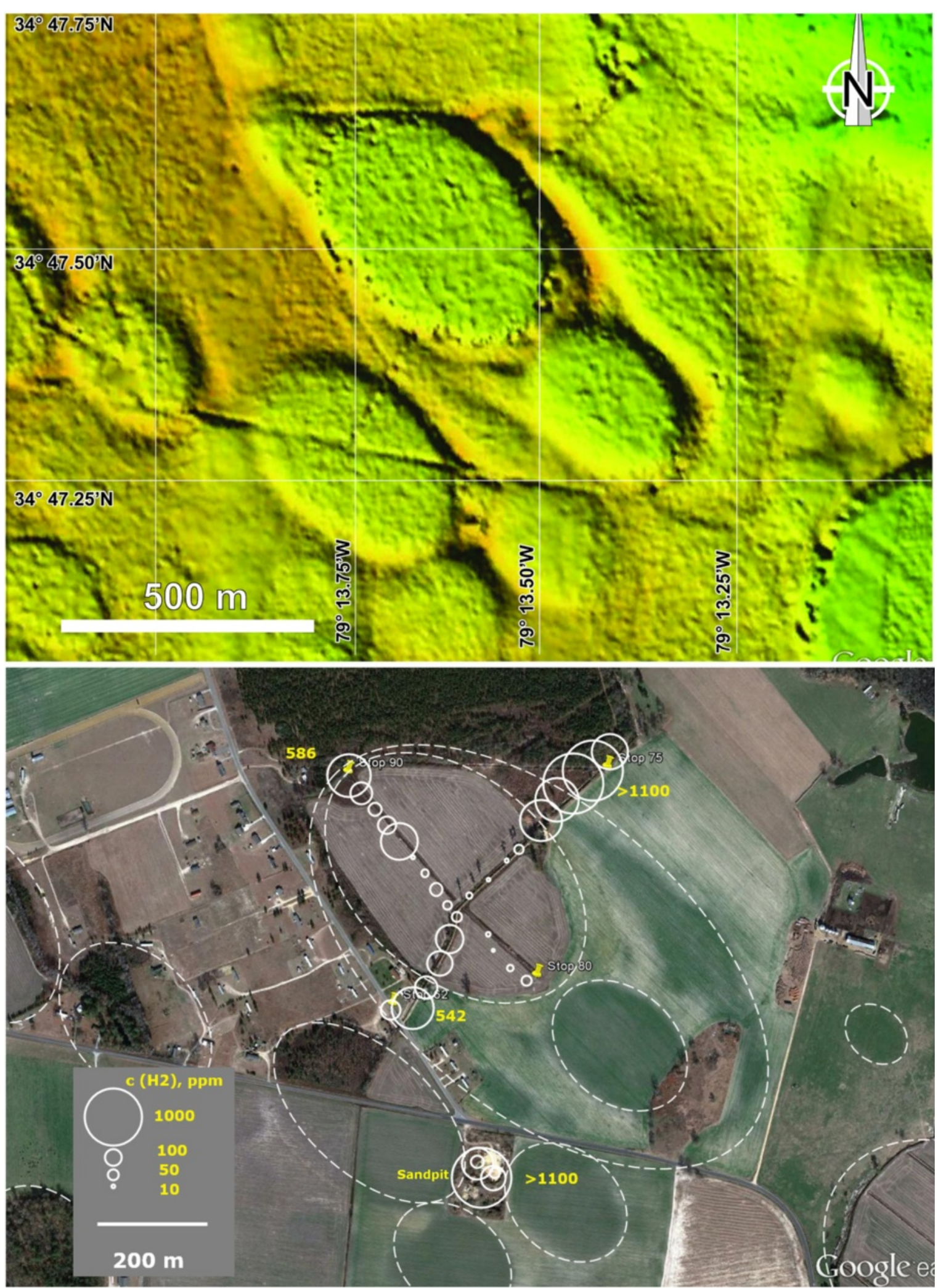

Fig. 2 Subsoil $\mathrm{H}_{2}$ concentration measurements at Arthur Road Bay and Arthur Road Sandpit (lower image). Dashed lines outline the bays. Upper image is a LiDAR image showing the relief of the lower image. Profile lines follow ditches (dark lines in the lower photograph). Date of measurements 14 March 2012. LiDAR image is from the site cintos.org 


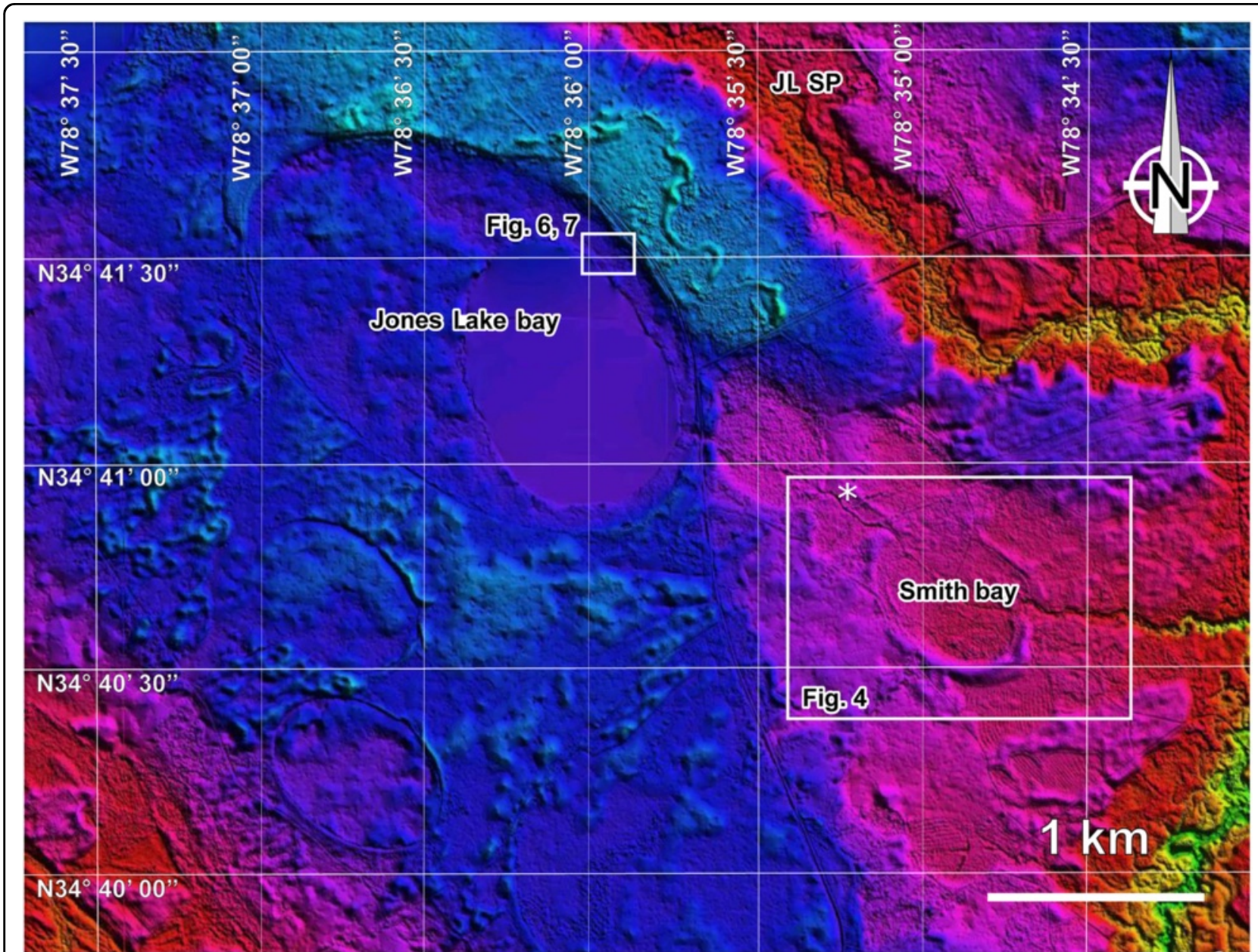

Fig. 3 LiDAR image with the locations of sites shown in Figs. 4, 6, and 7. JLSP Jones Lake Sandpit. The asterisk is the intersection zone for Smith Bay and unnamed bay. LiDAR image is from the site cintos.org

distribution of the shallow subcrops of the NC Coastal Plain. The features known as Carolina bays postdate the formation of the terraced topography.

Carolina bays are dynamically active features. According to Cohen et al. (1999), they originated during the Pleistocene. A relatively new technique for dating quartz grains, optically stimulated luminescence (OSL), has helped to refine the time frame of bay formation. Ivester et al. (2004) used this dating method to establish the multiple phases of bay evolution during the past 100,000 years. Brooks et al. (2010) concluded that most of the bays formed during the late Pleistocene, and Frey (1954) and Thom (1970) provided evidence for recent enlargement of existing bays. Moore et al. (2014) demonstrated geomorphologically and stratigraphically that these bays migrate through their own lacustrine deposits and calculated the migration rate from a series of OSL dates. In this study, we document an actively forming bay.

\section{Methods}

Study sites

The study sites (Figs. 1 and 3 and Table 1) are three prominent Carolina bays (Arthur Road Bay (Fig. 2), Smith Bay (Figs. 3 and 4), and Jones Lake Bay (Fig. 3)), and four smaller-scale detailed study sites associated with them. The detailed study sites include two sandpits (Arthur Road Sandpit and Jones Lake Sandpit), a small, recently formed bay-like feature associated with Jones Lake and a bay intersection area (between Smith Bay and an unnamed bay). All the study sites are on public land in Bladen County, except Arthur Road Bay and the sandpit located in Robeson County, which are privately owned. These public lands include Bladen Lakes State Forest, Turnbull Creek Educational State Forest, and Jones Lake State Park. The bays are naturally well preserved in these areas.

The Arthur Road sites are situated on surficial units that are Pliocene in age. The Smith Bay and Jones Bay 

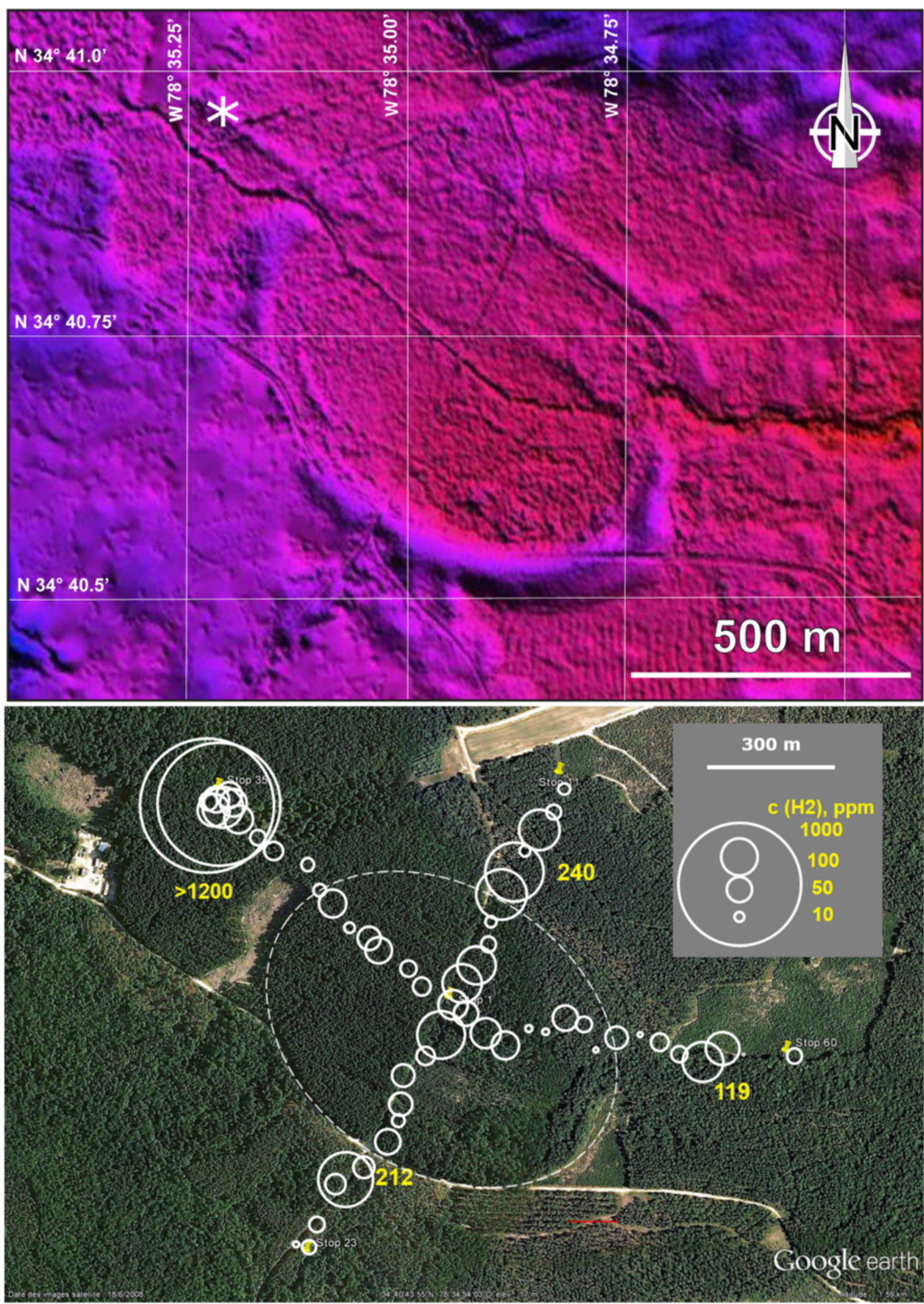

Fig. 4 An example of the subsoil hydrogen concentration measurements made in Smith Bay (lower image). Upper image is the corresponding LiDAR image. The asterisk is the intersection zone for Smith Bay and unnamed bay. Dashed lines outline Smith Bay. Date of measurements 09 March 2012. LiDAR image is from the site cintos.org 
Table 1 Gas chromatography (GC) measurements of soil gas samples

\begin{tabular}{|c|c|c|c|c|c|c|c|c|c|c|c|}
\hline \multirow[t]{2}{*}{ Work site } & \multirow{2}{*}{$\begin{array}{l}\text { Sample index } \\
\text { number }\end{array}$} & \multirow[t]{2}{*}{${ }^{\circ} \operatorname{dec} N$} & \multirow[t]{2}{*}{${ }^{\circ} \mathrm{dec} W$} & \multirow{2}{*}{$\begin{array}{l}\mathrm{H}_{2} \text { measured } \\
\text { in the field (ppm) }\end{array}$} & \multicolumn{7}{|c|}{ GC measurements } \\
\hline & & & & & $\begin{array}{l}\mathrm{H}_{2} \\
\text { (ppm) }\end{array}$ & $\begin{array}{l}\mathrm{O}_{2}+\mathrm{Ar} \\
(\%)\end{array}$ & $\begin{array}{l}\mathrm{N}_{2} \\
(\%)\end{array}$ & $\begin{array}{l}\mathrm{CH}_{4} \\
\text { (ppm) }\end{array}$ & $\begin{array}{l}\mathrm{CO}_{2} \\
(\%)\end{array}$ & $\begin{array}{l}\mathrm{C}_{2} \mathrm{H}_{6} \\
\text { (ppm) }\end{array}$ & $\begin{array}{l}\mathrm{C}_{3} \mathrm{H}_{8} \\
\text { (ppm) }\end{array}$ \\
\hline Arthur Road Bay & & 34.7939167 & -79.2296667 & 586 & 275 & 20.05 & 79.30 & 11 & 0.62 & 1 & 2 \\
\hline Arthur Road Sandpit & & 34.7869444 & -79.2266667 & SAT & 605 & 19.37 & 79.28 & 735 & 1.21 & 1 & 1 \\
\hline $\begin{array}{l}\text { Arthur Road Sandpit, } \\
\text { bubbles }\end{array}$ & & 34.7870556 & -79.2269167 & - & 0 & 2.84 & 35.04 & $53.57 \%$ & 8.56 & 0 & 0 \\
\hline \multirow[t]{3}{*}{ Smith Bay } & 1 & 34.6824722 & -78.5870694 & 659 & 179 & 20.23 & 79.26 & 15 & 0.50 & 2 & 2 \\
\hline & 2 & & & 715 & 146 & 20.32 & 79.15 & 11 & 0.51 & 0 & 0 \\
\hline & 3 & & & 574 & 296 & 20.38 & 79.40 & 17 & 0.20 & 2 & 2 \\
\hline \multirow{4}{*}{$\begin{array}{l}\text { Small new structure inside } \\
\text { Jones Lake Bay }\end{array}$} & 1 & 34.6930278 & -78.6004722 & 210 & 107 & 20.12 & 79.61 & 194 & 0.23 & 0 & 0 \\
\hline & 2 & 34.6930556 & -78.6008056 & 391 & 167 & 16.51 & 79.35 & 27468 & 1.38 & 0 & 0 \\
\hline & 3 & 34.6928131 & -78.6003308 & 477 & 202 & 20.00 & 78.11 & 5875 & 1.28 & 0 & 0 \\
\hline & 4 & 34.6928232 & -78.6003460 & 815 & 463 & 18.67 & 78.66 & 13783 & 1.24 & 0 & 0 \\
\hline \multirow[t]{3}{*}{ Jones Lake Sandpit } & 1 & 34.7001111 & -78.5867222 & $3700^{*}$ & 698 & 14.54 & 84.02 & 244 & 1.34 & 0 & 0 \\
\hline & 2 & 34.7001111 & -78.5872500 & 719 & 245 & 20.34 & 79.30 & 15 & 0.33 & 0 & 0 \\
\hline & 3 & 34.7001111 & -78.5867222 & SAT & 1043 & 14.78 & 82.12 & 392 & 2.96 & 0 & 0 \\
\hline
\end{tabular}

Data for all field $\mathrm{H}_{2}$ measurements were obtained with a GA2000 Plus detector, except in fields marked with *, which were measured with the MDS detector. Total gas measured for each sample is equal to $100 \%$. Discrepancies between field measurements and laboratory measurements are attributable to the sampling method (see explanation in "Field methods" subsection). Field measurements were usually about twice the laboratory measurements, except where sampling failed. For all field measurements, see Additional file 1: Table SI-1

SAT saturation (overload) of the detector, ${ }^{\circ} \mathrm{dec}$ coordinates in decimal degrees

localities occur on Middle to Early Pleistocene deposits (see Abbott et al. 2011 for their Figs. 4 and 5). The surficial units at all the sites overlie Cretaceous formations (see Fig. 6 in Abbott et al. 2011).

\section{Site selection}

We chose the study sites using satellite images, by reviewing areas that included a high density of bays with a variety of dimensions, that were easy to access and represented various ages deduced from the geomorphology. We identified the bays using satellite images from Google Earth and Google Earth Pro. LiDAR images were downloaded from the site cintos.org. We measured the $\mathrm{H}_{2}$ concentrations along profiles that transected the entire bays, starting outside the bay rims at a distance equivalent to half the diameters of the bays. This allowed us to determine the point on the profile at which $\mathrm{H}_{2}$ started to increase around the bays.

\section{Field methods}

Field measurements of the soil gas concentrations were made with a method modified from previously described techniques (Battani et al. 2010; Rogozhin et al. 2010; Garcia et al. 2012; Sukhanova et al. 2013; Larin et al. 2014). Small holes were drilled with a portable perforator using a $120 \mathrm{~cm}$ long drilling bit with a $12 \mathrm{~mm}$ diameter. A thin steel perforated tube was then inserted into the hole and the upper part was plugged with
Plasticine. We adapted the length of the tube $(10,30$, 100 , or $120 \mathrm{~cm}$ ) to the depth of the water table. The soil gas samples were collected in Vacutainer ${ }^{\circ}$ tubes. Before sampling, a vacuum $\left(10^{-4} \mathrm{mbar}\right)$ was established in each tube using a turbomolecular pump. Experiments with a $2 \mathrm{~m}$ long probe were conducted with a Gas Vapor Probe Kit from AMS Inc., American Falls, ID, USA. This kit has a retractable tip, which allows the soil gas to be sampled at a specific depth.

Two hydrogen gas analyzers were used to measure $\mathrm{H}_{2}$ in the field. The first was a palladium-based metalinsulator semiconductor detector provided by the Moscow Engineering Physics Institute, Russia, which includes three sensors with different ranges of sensitivity to $\mathrm{H}_{2}(0.5-50,50-1000$, and $1000-16,000 \mathrm{ppm})$. This detector is selective for $\mathrm{H}_{2}$ and is not affected by $\mathrm{H}_{2} \mathrm{~S}$, $\mathrm{CO}$, or any other gas. It has demonstrated excellent efficiency in several studies in which $\mathrm{H}_{2}$ was measured or monitored (Firstov and Shirokov 2005; Rogozhin et al. 2010; Sukhanova et al. 2013). The second gas analyzer was the landfill GA2000 Plus multi-gas detector by Geotech ${ }^{\ominus}$ Leamington Spa, UK, equipped with a $\mathrm{H}_{2}$-sensitive electrochemical cell with a sensitivity for $\mathrm{H}_{2}$ ranging from 1 to $1100 \mathrm{ppm}$. Water filters (Pall Acro ${ }^{\circ}$ 50, $0.45 \mu \mathrm{m}$ ) were used to prevent humidity penetrating the detectors. Detector accuracy was first checked in the laboratory using gas mixtures with $\mathrm{H}_{2}$ concentrations of 100 and $1000 \mathrm{ppm}$ in air-like mixtures $\left(80 \% \mathrm{~N}_{2}, 20 \%\right.$ 
$\mathrm{O}_{2}$ ). The relative accuracy of the detectors was "within $\pm 10 \%$." The results of all field tests are shown in Additional file 1: Table SI-1.

\section{Laboratory analyses}

Laboratory analyses were performed to determine the molecular compositions of gas samples in Vacutainer ${ }^{\oplus}$ tubes using gas chromatography (GC), and the results were compared with the measurements made in the field. The chromatograph used was a VARIAN 3800 by Agilent Technologies, Santa Clara, CA, USA, which is equipped with several columns in series and three detectors: two thermal conductivity detectors and one flame ionization detector. The analytical results are given with a precision of $\pm 0.1 \%$. Each analysis was bracketed with blanks.

The compositions of the collected gas samples showed that air made an important contribution, which is very normal for soil gas. The values determined with the GC analysis were always lower than the field measurements, because of the sampling method used. The samples were measured after the maximum concentration of $\mathrm{H}_{2}$ was reached on the field detector, when its value started to decrease. Therefore, the samples were always diluted because the soil gas mixes with air present in the $\mathrm{H}_{2}$ detector system.

\section{Results}

\section{Arthur Road Bay}

The Arthur Road Bay is an oval-shaped depression (580 $\mathrm{m}$ long and $360 \mathrm{~m}$ wide) with a sand rim (Fig. 2). It has been modified by anthropogenic activity (draining and clearing). Two ditches drain water from this bay. Data were collected along two profiles that transected the bay perpendicularly (Fig. 2). Gas measurements were made every $50 \mathrm{~m}$ along both profiles (Fig. 2). The maximum detected $\mathrm{H}_{2}$ concentration was $>0.11 \%$ (detector saturation), with an average of 233 ppm across 23 measurements (Additional file 1: Table SI-1). Traces of $\mathrm{C}_{2}+$ hydrocarbons were detected in the laboratory analysis of one soil gas sample (Arthur Road Bay, Table 1).

\section{Arthur Road sandpit}

Additional measurements were collected in a sandpit located $500 \mathrm{~m}$ south of the Bay's center (Fig. 2). The pit was surrounded to its north, east, and west by at least three other bays (Fig. 2). The maximum $\mathrm{H}_{2}$ concentration detected at the pit was also $>0.11 \%$ (detector saturation), with an average of 313 ppm across six measurements. The laboratory analysis of one soil gas sample provided evidence of $\mathrm{C}_{2}+$ hydrocarbons (Table 1 ). Some parts of the sandpit included stagnant water pools that were degassing natural bubbles of gas. A GC analysis revealed a high concentration of methane (54\%) in the bubbles (Table 1), which could suggest high biological activity of methanogens using the $\mathrm{H}_{2}$.

\section{Smith Bay}

Smith Bay is an oval-shaped depression with a sand rim (Figs. 3 and 4). This depression is $1-3 \mathrm{~m}$ deep, $720 \mathrm{~m}$ long, and $545 \mathrm{~m}$ wide. The bay formed on a probable middle Pleistocene landscape. Inside its rim, it is mantled with 1-2 $\mathrm{m}$ of Holocene peat. The vegetation patterns, swamp distribution, and the topography sharply delimit the bay's outline and its rim. Water drains from the bay in two ditches that cross near the center of the bay. Data were collected along two profiles that followed the ditches (Fig. 4). A maximum concentration of $\mathrm{H}_{2}>1200 \mathrm{ppm}$ (saturation of the GA2000 detector) was detected outside the northwestern border of the bay (see Fig. 4), near the intersection of Smith Bay and a smaller unnamed bay to the northwest. Three other sites with $\mathrm{H}_{2}$ peaks $>1200$ ppm were situated where the transects coincide with the sand rims bordering the bays (Fig. 4). Elevated concentrations of $\mathrm{H}_{2}$ were also detected in the center of the bay. The $\mathrm{H}_{2}$ concentration decreased to near-zero values outside the sand rim.

\section{Intersection zone for Smith Bay and unnamed bay}

The maximum $\mathrm{H}_{2}$ concentration $(>0.12 \%)$ occurred at a site that coincided with the overlap or intersection of the rims of the two bay (Smith Bay and an unnamed bay situated to the northwest) (Fig. 4). Here, the surface was mantled with peat (70-80 cm thick)-overlying sand. In a small area of the bay overlap where high $\mathrm{H}_{2}$ concentrations were detected, ten measurements were made within a circumference of $5 \mathrm{~m}$. Only one other point inside this circumference displayed a similarly high $\mathrm{H}_{2}$ concentration (Additional file 1: Table SI-1). The subsoil $\mathrm{H}_{2}$ concentrations here were highly variable, probably because the porosity and macropore distribution of the soil were heterogeneous.

We performed an experiment with a $2 \mathrm{~m}$ long probe near the recorded maximum $\mathrm{H}_{2}$ concentration to measure the gradient of the $\mathrm{H}_{2}$ concentration. Measurements were made at several depths (every $50 \mathrm{~cm}$ ) using a system of retractable tips (Gas Vapor Probe Kit). An increase in the $\mathrm{H}_{2}$ concentration with depth (Fig. 5) was observed at the transition from peat to sand (within a $50-100 \mathrm{~cm}$ interval), and the maximum concentration was in the coarse sand. As well as $\mathrm{H}_{2}$ and $\mathrm{CH}_{4}$ anomalies, $\mathrm{C} 2+$ hydrocarbons were also detected in samples from this location (Smith Bay 1-3, Table 1) with laboratory measurements.

\section{Jones Lake Bay}

Jones Lake Bay is a very large bay $(2400 \times 1500 \mathrm{~m})$, with an almost perfect inner elliptical lake (Jones Lake) in the 


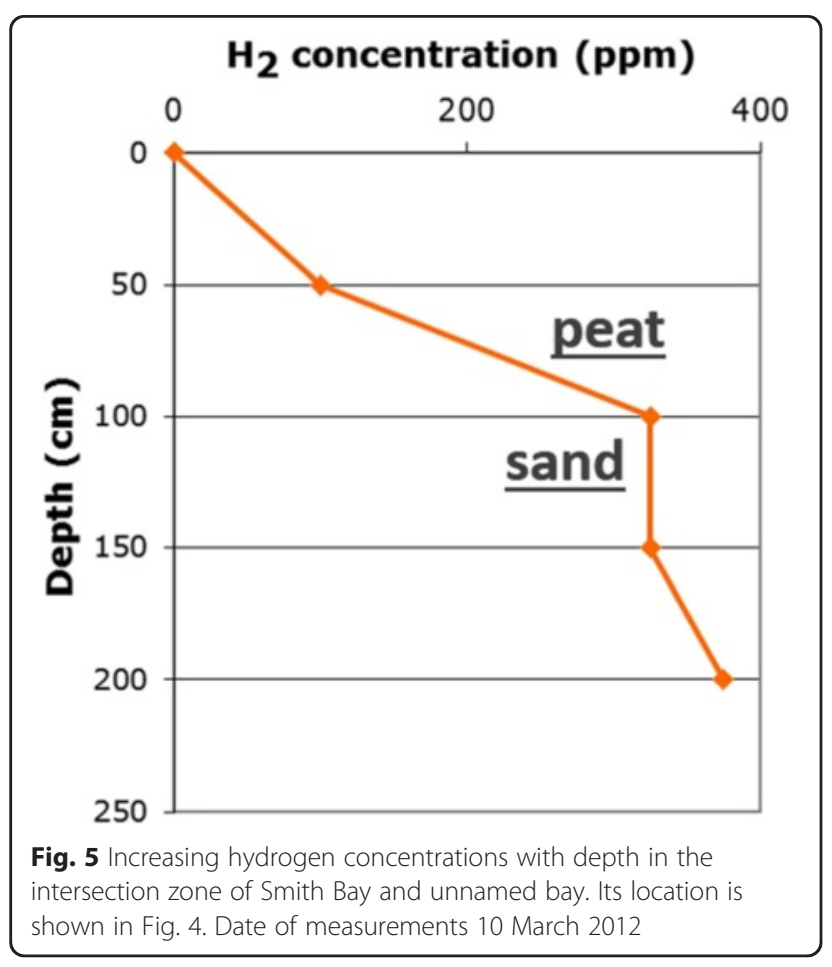

southeastern part (Fig. 3). Like the other bays studied, the limits of the bay are clearly detectable from the vegetation. The bay is covered with peat and is densely vegetated on the inside, whereas outside it, the soils are sandy and have rare undergrowth. The bay rim consists of soils with coarse sand derived from the underlying deposits of probable Early Pleistocene age. $\mathrm{H}_{2}$ was only detected within the confines of the bay border. The maximum concentration of $\mathrm{H}_{2}$ was $815 \mathrm{ppm}$, detected in coarse sand. We detected no traces of $\mathrm{H}_{2}$ outside the bay limits (Additional file 1: Figure SI-1 and Additional file 1: Table SI-1).

\section{Jones Lake sandpit}

We also measured the $\mathrm{H}_{2}$ concentrations in a sandpit near the Jones Lake Bay (Fig. 3 and Additional file 1: Figure SI1 , upper right part). We detected very high concentrations of $\mathrm{H}_{2}$ at the bottom of the peat, 3-4 m below the ground surface, in clayey sand. The maximum concentration was $0.37 \% \mathrm{H}_{2}$, measured with the Gas Vapor Probe Kit. The average $\mathrm{H}_{2}$ concentration was $0.1 \%$ across seven measurements (Additional file 1: Table SI-1).

\section{Small new structure inside Jones Lake Bay}

Detailed studies were conducted in a small area outside the lake in Jones Lake Bay (Fig. 3, insets in Figs. 6 and 7), where high $\mathrm{H}_{2}$ levels (up to $815 \mathrm{ppm}$ ) were detected in the soil. This site is a relatively small near-circular wet area (diameter $\sim 60 \mathrm{~m}$ ) where the tall trees suddenly withered naturally in 2008-2009, which was confirmed by the park rangers who manage the reserve. Satellite images taken in 2008 were compared with images taken in 2009 (Fig. 6). The trees probably withered (see panoramic picture, Additional file 1: Figure SI-2) in response to the increase in soil water saturation (water table depth of only $10-15 \mathrm{~cm}$ ) or from the negative impact of another unknown process affecting the vegetation. Despite the very high water table, an $\mathrm{H}_{2}$ concentration of 210 ppm was detected in the upper few centimeters $(<10 \mathrm{~cm})$ of the soil in the center of the newly forming bay (Fig. 7). The depression of the newly forming bay was less than $1 \mathrm{~m}$, according to field measurements made with an altimeter.

Two detailed cross-sections of the new bay, showing the $\mathrm{H}_{2}$ concentrations and distances, with measurements made every meter, are shown in Fig. 7. In both sections, the highest $\mathrm{H}_{2}$ concentrations were detected on the new bay's borders. Laboratory measurements of the chemical composition of the gas revealed that relatively high concentrations of methane were associated with $\mathrm{H}_{2}$ (Table 1). No heavier hydrocarbons were detected. This wet area with $\mathrm{H}_{2}$ anomalies is very similar to a recently formed round feature studied by our team in Russia, near the city of Electrostal, close to Moscow (Larin et al. 2014).

\section{Estimation of $\mathrm{H}_{2}$ fluxes}

In this study, the maximum $\mathrm{H}_{2}$ contents occurred in coarse sand along the rims of the bays and were clearly not associated with wetlands. Because $\mathrm{H}_{2}$ is a highly diffusive gas, it cannot remain for long in a porous medium-like coarse sand. We used a $2 \mathrm{~m}$ long probe (Fig. 5) to demonstrate the gradient in the $\mathrm{H}_{2}$ concentration, and we interpret this $\mathrm{H}_{2}$ gradient as the result of the diffusive flow of $\mathrm{H}_{2}$.

We calculated the $\mathrm{H}_{2}$ flow using the classical Fick's law of diffusion:

$$
F=\Phi D \operatorname{grad}[C]
$$

where $F$ is the gas flow, $\delta$ is the exchange area or the effective porosity of a homogeneous porous medium, $D$ is the diffusion coefficient of the gas in air, $[C]$ is the gas concentration, and grad is the gradient.

The diffusion coefficient $(D)$ for $\mathrm{H}_{2}$ in air was taken to be $7.7 \times 10^{-5} \mathrm{~m}^{2} / \mathrm{s}$ (Cussler 2009).

The gradients were estimated to be twice the average concentration measured in the perforation, depending on the level of the groundwater. Effective porosity was estimated as follows: for wet swamp, 10-20\%; for dried swamp, 10-25 \%; for sand, 35-45 \%; and for soil, 25-35\% (Hough 1969; Swiss standard 1999; Das 2008).

To establish the zonation in the $\mathrm{H}_{2}$ concentrations observed in specific bays, the average $\mathrm{H}_{2}$ concentrations were estimated for each defined zone in each bay. Four concentric oval-shaped rings were defined for each bay, 

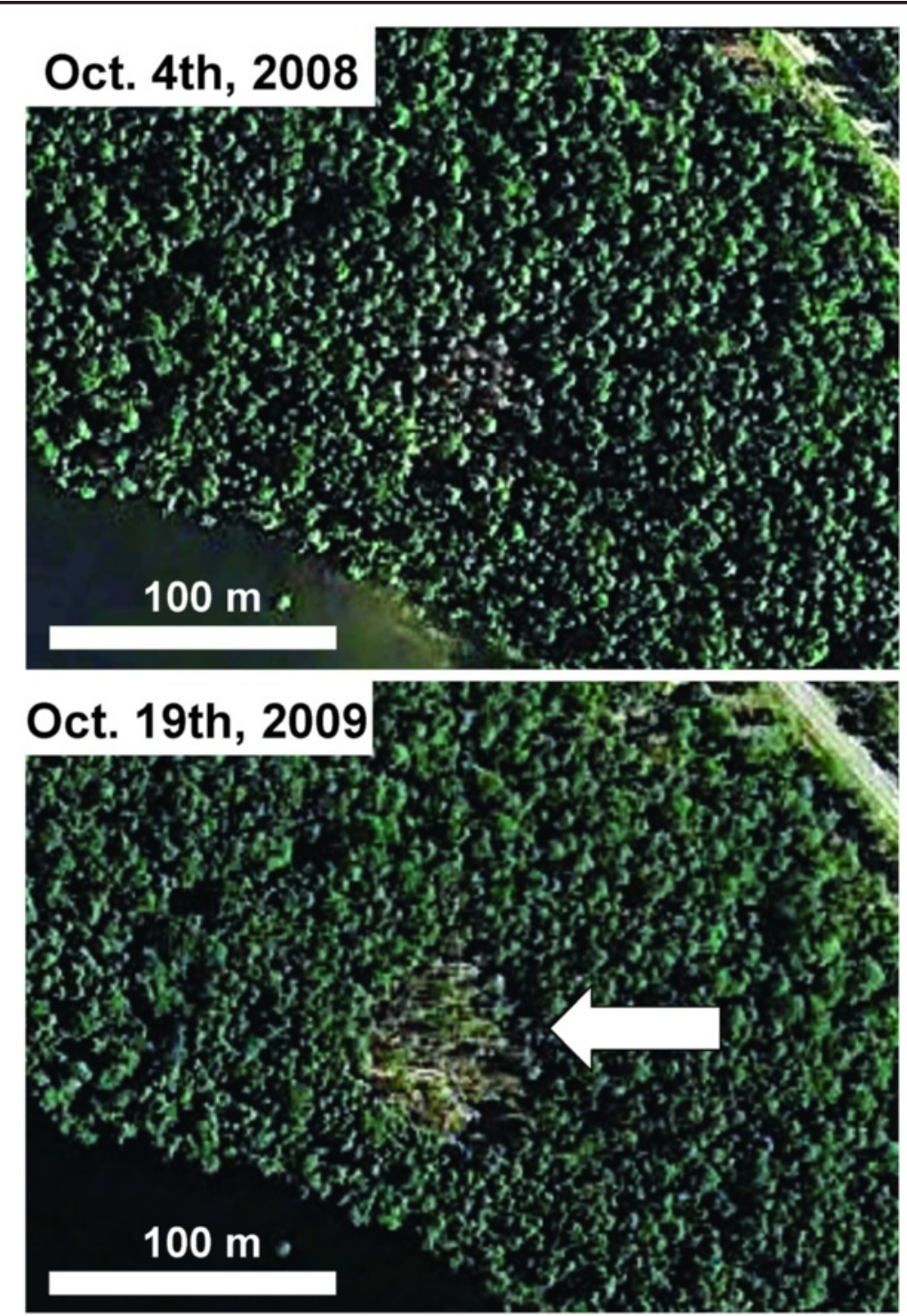

Fig. 6 Appearance of new structure inside the Jones Lake Bay. Upper panel: satellite image of part of Jones Lake Bay in 2008. Lower panel: satellite image of the same part of Jones Lake Bay 1 year later. Its location is shown in Fig. 3. Note the appearance of a circle about $60 \mathrm{~m}$ in diameter where the forest is damaged

corresponding to the center of the bay, the internal shore, the external shore, and the outside zone. For each zone, the average $\mathrm{H}_{2}$ concentration was estimated specifically from field measurements. The daily $\mathrm{H}_{2}$ flow was calculated for each zone, and the sum of the flows calculated for each zone provided the total flow within the bay.

In the Smith Bay, the estimated daily $\mathrm{H}_{2}$ flow was $750-1000 \mathrm{~m}^{3} /$ day over an area of $1.14 \mathrm{~km}^{2}$ (660$880 \mathrm{~m}^{3} /$ day $\left./ \mathrm{km}^{2}\right)$. In the Arthur Road Bay, the estimated daily $\mathrm{H}_{2}$ flow was $1000-1370 \mathrm{~m}^{3} /$ day over an area of $0.48 \mathrm{~km}^{2}\left(2240-3060 \mathrm{~m}^{3} /\right.$ day $\left./ \mathrm{km}^{2}\right)$. For Jones Lake Bay, the daily $\mathrm{H}_{2}$ flow was estimated to be $1120-2740 \mathrm{~m}^{3}$ / day for a surface area of $6.25 \mathrm{~km}^{2}\left(180-440 \mathrm{~m}^{3} /\right.$ day/ $\mathrm{km}^{2}$ ). For the small structure inside the large Jones Lake Bay, the daily $\mathrm{H}_{2}$ flow was estimated to be $21-31 \mathrm{~m}^{3}$ / day over a surface area of $0.007 \mathrm{~km}^{2}\left(3000-4400 \mathrm{~m}^{3} /\right.$ day $\left./ \mathrm{km}^{2}\right)$.

\section{Discussion}

The occurrence of molecular hydrogen in the soils of Carolina bays was discovered after noting the remarkable geomorphological similarity to depressions that emit $\mathrm{H}_{2}$ in the EEC in Russia (Sukhanova et al. 2013; Larin et al. 2014). In both cases, relatively high $\mathrm{H}_{2}$ concentrations were found in the soil gas of the bay-like features. This study suggests that Carolina bays are geomorphological features related to the occurrence of 

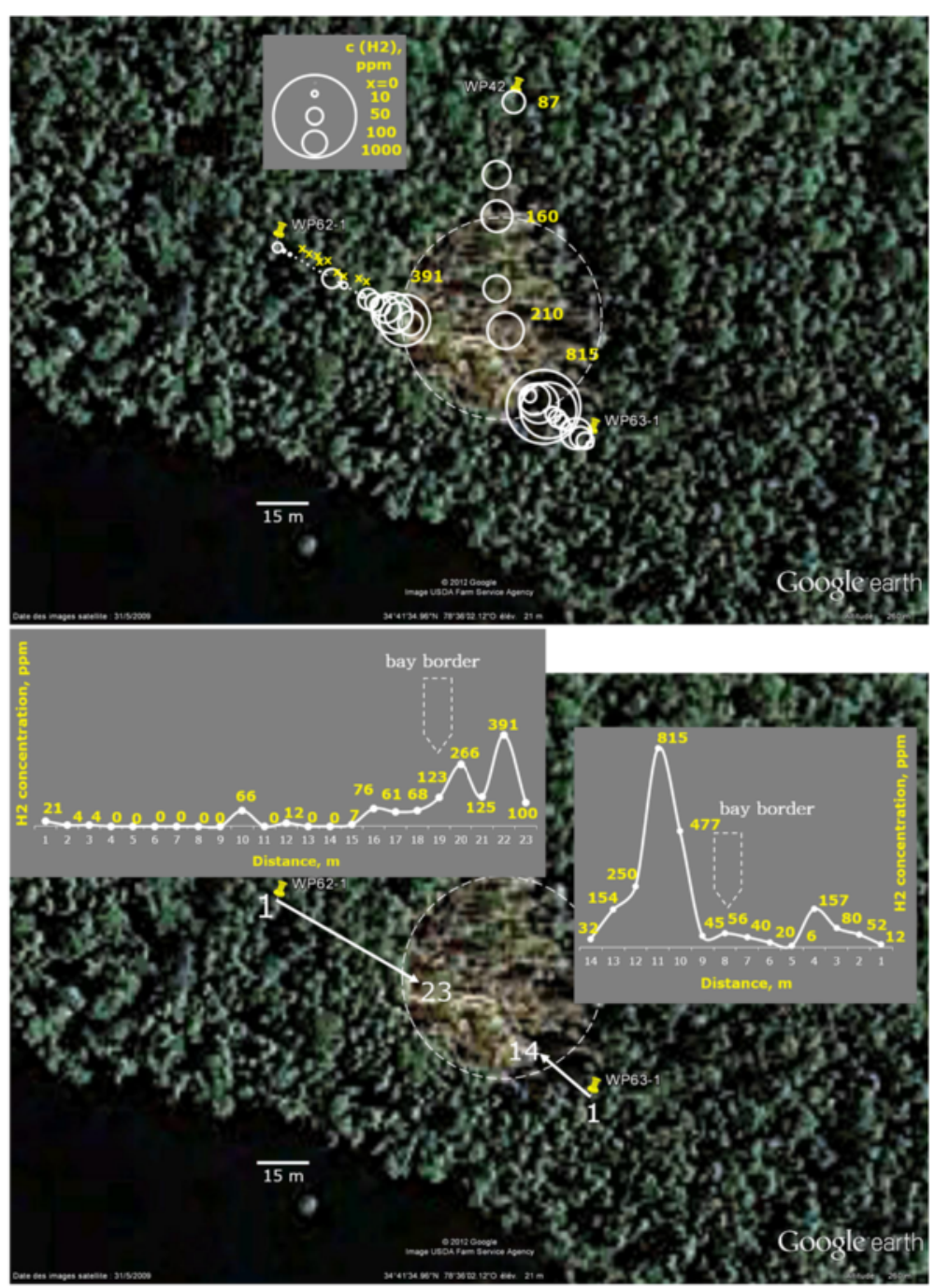

Fig. 7 Subsoil hydrogen concentrations in Jones Lake Bay. Its location is shown in Fig. 3. Dashed line shows the limits of the new structure. Geochemistry and geomorphology correlate perfectly, defining the borders of the structure. Date of measurements 13 March 2012

$\mathrm{H}_{2}$ rather than the results of simple depositional processes along coastal plains (Stolt and Rabenhorst 1987). Therefore, the causal link between the origin of these morphological features and their association with molecular hydrogen must be established. This bay-hydrogen association suggests a connection between fluid seepage from depth towards the atmosphere (deep geological control) and the surficial geomorphic expression of Carolina bays. A possible interpretation might be that Carolina bays are not only focal points for groundwater recharge, as suggested by Grant et al. (1998), but also a morphological expression of fluid seepage from depth toward the atmosphere.

\section{Origin of hydrogen}

Carolina bays are natural depressions, commonly filled with water and organic deposits (peat). Consequently, we should consider whether the source of $\mathrm{H}_{2}$ might be attributable to superficial biological activity under reducing conditions (Sugimoto and Fujita 2006). However, our study clearly shows that the highest concentrations of $\mathrm{H}_{2}$ systematically occurred in the sand deposits on the rims of the bays, where there was no peat cover (Figs. 2, 4, and 7). We also detected $\mathrm{H}_{2}$ at a depth of $2 \mathrm{~m}, 120 \mathrm{~cm}$ below the level of the peat (Fig. 5), which reduces the likelihood of a verynear-surface origin for the $\mathrm{H}_{2}$. Furthermore, the $\mathrm{H}_{2}$ concentrations measured in the wetlands were low compared with the measurements made in sand. The $\mathrm{H}_{2}$ concentrations also increased with depth (Fig. 5, Additional file 1: Table SI-1), and the maximum concentration measured, $0.37 \mathrm{vol} . \%$, was detected at a depth of $5 \mathrm{~m}$ below ground level in sandpit 2 (Additional file 1: Table SI-1), in a clay and sand substrate. Although slight background $\mathrm{H}_{2}$ associated with biological activity cannot be excluded, these 
observations make a purely superficial origin for the $\mathrm{H}_{2}$ highly improbable. It is also generally believed that the free $\mathrm{H}_{2}$ produced by bacteria remains at low concentrations because it is rapidly consumed by methanogenic bacteria and soil enzymes (Conrad and Seiler 1981). Indeed, the biological production of $\mathrm{H}_{2}$ occurs within bacterial consortia, where this valuable chemical energy source is constantly consumed and consequently remains at low concentrations (high $\mathrm{H}_{2}$ concentrations inhibit $\mathrm{H}_{2}$-producing bacteria). $\mathrm{H}_{2}$ is considered to be the most energetic substrate, able to sustain lithoautotrophic ecosystems in subsurface environments, where it is readily consumed (Nealson et al. 2005). Therefore, such high concentrations in soil gases are more probably linked to geochemical $\mathrm{H}_{2}$-producing processes.

Inventories of the geological controls on the sources of natural hydrogen have been made by Apps and Van De Kamp (1993) and Smith et al. (2005). The natural settings for hydrogen include hydrocarbon-bearing basins, young organic-rich sediments, coal beds, fault zones, extrusive igneous rocks, alkaline igneous complexes, geothermal fields, crystalline basements, potash-bearing strata, salt-bearing strata, and ultramafic rocks. The geologically controlled sources of natural $\mathrm{H}_{2}$ can be grouped according to four main families of processes: (1) water hydrolysis processes (several processes that include the oxidation of ferrous minerals, radiolysis, cataclasis, and metamorphism); (2) organic matter decay (including thermal maturation); (3) methane and/or ammonia decomposition during metamorphism; and (4) deep Earth degassing. The alteration of $\mathrm{Fe}(\mathrm{II})$-bearing minerals is the most commonly reported source of natural $\mathrm{H}_{2}$ seepages on Earth, notably at mid-oceanic ridges and in ophiolitic massifs, where mafic and ultramafic are altered. Moreover, a recent study suggested that the $\mathrm{H}_{2}$ production from the Precambrian continental lithosphere has been underestimated (Sherwood Lollar et al. 2014).

Several ultramafic suites in the eastern Piedmont Province of $\mathrm{NC}$ are interpreted as parts of ophiolite sequences (Butler 1989). In particular, the Halifax County complex, described in detail by Kite (1982) and Kite and Stoddard (1984), and interpreted as ophiolitic, is locally overlain by Coastal Plain deposits. Kite and Stoddard (1984) also proposed that an extensive ophiolitic belt might occur beneath the Coastal Plain (also see Lawrence and Hoffman 1993). However, the available deep drilling data are insufficient to define exactly where these rocks are located (and at what depth). The alteration of peridotite, in both oceanic and continental contexts, produces $\mathrm{H}_{2}$ with the reduction of water by $\mathrm{Fe}(\mathrm{II})$, contained especially in fayalite (olivine ferric phase). This process, which is associated with serpentinization, consumes water and is responsible for mineral hydration. Other minerals, as well as olivine, contain $\mathrm{Fe}(\mathrm{II})$. In particular, clays (ferrous illites, chlorites, or smectites) can release $\mathrm{Fe}^{2+}$ ions in solution under certain conditions. The oxidation of dissolved ferrous ions by water produces $\mathrm{H}_{2}$, and this type of process could be a potential source of $\mathrm{H}_{2}$ if the sedimentary pile is clay-rich and provides a substantial reservoir of Fe(II).

It has been suggested that $\mathrm{H}_{2}$ forms during rock-water reactions (e.g., cataclasis) between fresh rock surfaces containing radicals (Sugisaki et al. 1983) and by the redox conversion of hydroxyls to peroxy groups in silicates (Freund et al. 2002). $\mathrm{H}_{2}$ can also be formed in uranium-, thorium-, and potassium-rich geological settings, by the radiolysis of water and/or organic matter, and also by the reaction of water with newly formed elements (Savchenko 1958; Lin et al. 2005). However, the quantities of $\mathrm{H}_{2}$ that can be produced by these mechanisms are limited, and therefore they cannot explain the $\mathrm{H}_{2}$ flows estimated in this study.

Another possible source of $\mathrm{H}_{2}$ is the decay of solid or dissolved organic matter, either by bacterial decomposition in sediments during diagenesis and/or later during thermal maturation, which produces $\mathrm{H}_{2}$ during the ultimate cracking of organic matter. Thermal maturation can be ruled out on the coastal plain of eastern USA because the sedimentary cover of NC and SC is not thick enough to produce the burial depth necessary for $\mathrm{H}_{2}$ production by thermal maturation.

The decomposition of methane and/or ammonia at high temperatures (above $600{ }^{\circ} \mathrm{C}$ ) during metamorphism can produce $\mathrm{H}_{2}$. Such reactions can also produce dinitrogen. In the present case, we observed a diffusive flow of $\mathrm{H}_{2}$ in the soil, but because it was already mixed with atmospheric components, it was difficult to evaluate the gas components that evolved with it, which may help to clarify the origin of this molecular hydrogen.

The degassing of the Earth's mantle is usually ruled out based on our present understanding of the oxidation state of the upper mantle, and it is therefore not compatible with the high concentrations of dihydrogen detected here. However, because the amount of hydrogen that was originally incorporated into the Earth's interior is unknown, the oxidation state of the upper mantle may actually differ from the conclusions drawn from surface observations, which are necessarily indirect. A recently revised geochemical concept (Toulhoat et al. 2015), initially proposed by Larin (1993), suggests that the Earth's interior is enriched in hydrogen, which is supported by calculations and experiments with iron hydride (Isaev et al. 2007). Such a model is consistent with Ohmoto's suggestion (Ohmoto 1997) that the oxygenation of the atmosphere is linked to the evolution of the continental crust. Under these conditions, deeply stored hydrogen could slowly seep to the surface.

The daily $\mathrm{H}_{2}$ flows estimated in this study are quite important. For the largest structure, Jones Lake, they 
varied from 1120 to $2740 \mathrm{~m}^{3} /$ day. If the total number of Carolina bays spread along the Atlantic coast of the USA (about 500,000) is considered, it is clear that a large-scale process is involved, and the mechanism that produces this hydrogen must be efficient enough to sustain the observed $\mathrm{H}_{2}$ flow.

\section{Geometry and origin of Carolina bay structures}

Whatever the source of this hydrogen, the subsurface migration of the ultimate reduced gas must induce reactions with oxidized subsurface rocks and fluids. These reactions and the seepage routes taken might be associated with the initial formation of the elliptical geomorphic structures that are characteristic of Carolina bays. These landscape features develop exclusively in areas where unconsolidated sediments are present at the surface. This is the case in both Carolina and Russia, where the weathered bedrock below the soil consists of unconsolidated granular sediments (Larin et al. 2014). These structures are rarely seen in river valleys, where they are likely to be obscured by fluvial processes. However, a creek that crosses Smith Bay (Fig. 4) does not seem to greatly affect the form of the bay. This may indicate either the recent age of the creek or of Smith Bay.

A variety of compounds can form with the hydrogenation of rocks along the migration pathways of $\mathrm{H}_{2}$, including water, hydrocarbons, and acids. All these compounds are susceptible to mobilization and to $\mathrm{mi}-$ gration out of the reaction zone. In this way, hydrogen might induce an increase in the bulk porosity of the rocks during its vertical migration, and as a consequence, it is likely to create its own channel for vertical migration. All the associated processes (degassing, dewatering, and volume loss at depth) will generate subsidence at the land surface, thus forming rounded (circular or elliptical) depressions.

A study of similar depressions in the Ukraine suggested that water seepage from them is possible (Bixio et al. 2002). Therefore, water with dissolved hydrogen might be discharged onto the surface, creating swamps in some bays, such as the newly formed, small structure in Jones Lake Bay. This small depression, which appeared during the late 2000s, suggests a still active mechanism underlying the formation of some of the bays. Satellite images taken in 2008 show no sign of this structure, whereas 1 year later in 2009, it had become clearly visible (Fig. 6), with the loss of all the trees within it, within less than 1 year, which was probably related to the flooding of the area. The same rapid formation of a new structure, within only several years, has been observed in the Moscow region of Russia (Larin et al. 2014).

The highest concentrations of $\mathrm{H}_{2}$ occurred on the external slopes of the sandy rims of the Carolina bays, with moderate concentrations inside the bays and no $\mathrm{H}_{2}$ recorded at some distance from the bay limits (Figs. 2, 4, and 7). This distribution of $\mathrm{H}_{2}$ is similar to that in the structures studied in the EEC (Larin et al. 2014). The sand rims that border the bays (1-3 m higher than surrounding surface elevation; visible on LiDAR images in Fig. 3 and highlighted in Additional file 1: Figures SI-3 and SI-4) often showed the highest concentrations of $\mathrm{H}_{2}$. These zones appear to be the preferential drainage sites for $\mathrm{H}_{2}$-rich fluids moving toward the surface. Although the mechanisms of their formation and their association with higher concentrations of $\mathrm{H}_{2}$ are not yet understood, they may be linked to fault networks around the features or their peculiar petrological properties (notably the porosity of the rocks surrounding Carolina bays).

Field studies in the EEC have shown that bay-like features emitting $\mathrm{H}_{2}$ gas sometimes occur along structural trends, very probably corresponding to basement faults (Larin et al. 2014). Many studies have suggested that $\mathrm{H}_{2}$ anomalies are commonly related to faults (Wakita et al. 1980; Jones and Pirkle 1981; Ware et al. 1985; Sato et al. 1986; Shcherbakov and Kozlova 1986; McCarthy and McGuire 1998; Rogozhin et al. 2010), which act as fluid conduits. This suggests that $\mathrm{H}_{2}$-emitting features are genetically related to structural features of the crystalline basement. The available information on the deep geology of NC is insufficient to exactly define the locations of faults or their distances from these depressions (Lawrence and Hoffman 1993). This theory, together with the potential alignment of the bays along structural trends, suggests a close relationship between Carolina bays and the observed molecular hydrogen seepages from these potential geological structures.

The elliptical shape of Carolina bays is the feature that most significantly distinguishes them from the hydrogenseeping structures in the EEC, which usually have rounded shapes. The elliptical shape of Carolina bays could be interpreted as a consequence of the local stress regime. The long and short axes of the bays appear to occur parallel to the minimum and maximum horizontal stresses, as is the case for many calderas. The formation of stressinduced oval structures is well documented in calderas around mud volcano systems (Bonini 2012). Stress discharge will determine the predominant orientation of the vertical (or subvertical) fractures of crystalline basement rocks (Lawrence and Hoffman 1993). Indeed, on geological maps, faults are almost always parallel to the bays' orientation (Brown 1985). Consequently, the initially round (isometric) shape of the hydrogen stream would gradually become elliptical as it ascends through the upper layers of the lithosphere.

When Carolina bays are compared with the structures in the EEC (Larin et al. 2014), the chemical composition of the gases seeping from them and the flow rates of the 
gases are quite similar. The $\mathrm{H}_{2}$ concentrations range from tens to hundreds of parts per million. Small quantities of $\mathrm{CH}_{4}$ and its close homologues $(\mathrm{C} 2+)$ are also sometimes present locally. We observed similar links between the geochemistry, geomorphology, and the distributions of the $\mathrm{H}_{2}$ concentrations in the Carolina bays and the Russian structures: the highest concentrations commonly occurred on the external shores of these structures, with high $\mathrm{H}_{2}$ concentrations inside the structures and almost zero $\mathrm{H}_{2}$ outside the depressions. According to our estimates, larger bays showed greater absolute $\mathrm{H}_{2}$ flows, whereas smaller bays showed greater flows per unit of surface.

When soil scientists studied the hydrogen-seeping features in the EEC in Russia (Sukhanova et al. 2013; Polyanskaya et al. 2014), they found that molecular hydrogen seeps from these structures and that this seepage affects the soil layers by disturbing the vegetation and the microbial biomass. In areas of $\mathrm{H}_{2}$ seepage, the humus content decreases by a factor of 2-3 and the optical density of the humic acids is lower than in the surrounding areas. The fertility of arable lands decreases significantly, and they often become unsuitable for cultivation (Sukhanova et al. 2013). The total quantities and biomasses of bacterial cells and fungal spores and the lengths of fungal and actinomycete mycelia decrease (Polyanskaya et al. 2014). The soil bleaching associated with Carolina bays could also be similar to the bleaching phenomenon associated with the bay-like features in the EEC.

The size distribution of the Carolina bays indicates that the number of bays decreases as the surface area of the bays increases (Semlitsch 2000). In this, their size distribution has the same characteristics as the bay-like features in the EEC (Larin et al. 2014), indicating that they may have a common origin.

In summary, the rounded (elliptical) depressions in the Atlantic Coastal Plain, Province of the USA, and the rounded structures in the EEC show similar geomorphic features and size distributions, and they emit $\mathrm{H}_{2}$ at similar flow rates. All these similarities suggest a common origin and the same mechanism of formation for these features. We interpret them as the surficial marks of pathways of hydrogen-rich fluid migration. We interpret these bays as the results of local structural collapses associated with the rock alterations induced by $\mathrm{H}_{2-}$ enriched fluid flowing from the crust or deeper. Similar features can be seen in satellite images on all continents (except ice-covered Antarctica), suggesting that other analogous structures exist elsewhere in various settings.

\section{Conclusions}

The elliptical depressions known as Carolina bays in the USA are associated with $\mathrm{H}_{2}$ flows, as observed in similar surface features in the East European craton. This molecular hydrogen probably originates from geochemical processes taking place under the sedimentary pile and migrates towards the surface. If such $\mathrm{H}_{2}$ migration pathways exist, it is possible that this flow of $\mathrm{H}_{2}$ induces gas-rock interactions, forming shallow pathways. These pathways might link these $\mathrm{H}_{2}$ flows with the formation of surficial topographic anomalies that correspond to the Carolina bays, and this process might contribute to the active and ongoing development of these bays today. Our observations provide an alternative explanation to the former controversial theories on the formation of Carolina bays. We estimated the daily hydrogen flow to be quite high, up to $2700 \mathrm{~m}^{3}$, in some of these features. Evidence of the diffusive flow of $\mathrm{H}_{2}$ seeping from Carolina bays and its abundance suggests that the role of molecular hydrogen in the processes of the Earth's surface environments must be reconsidered. This reconsideration may influence our understanding of the dynamics and chemical processes of the biosphere and the atmosphere (Syvorotkin 2010).

\section{Additional file}

\section{Additional file 1: Supplementary information for article.}

\section{Abbreviations}

EEC: East European craton; GC: gas chromatography; NC: North Carolina; SC: South Carolina.

\section{Competing interests}

The authors declare that they have no competing interests.

\section{Authors' contributions}

VZ, VB, ED, and NL proposed the topic and conceived and designed the study. All authors performed the experimental study. VZ, VB, ED, and NL analyzed the data and participated in their interpretation. VB, ED, and KF collaborated with the corresponding author VZ in the preparation of the manuscript. All authors have read and approved the final manuscript.

\section{Acknowledgments}

We thank North Carolina State geologist, Dr. Kenneth B. Taylor, for facilitating this multinational oil- and gas-related investigation in North Carolina and the staff of Bladen Lakes State Forest, Turnbull Creek Educational State Forest, and Jones Lake State Park for assisting with the logistics of the field work and providing permits for us to access and collect data at the study sites.

\section{Author details}

${ }^{1}$ IFP Energies Nouvelles, 1 et 4 avenue de Bois Préau, 92852 Rueil-Malmaison Cedex, France. ${ }^{2}$ Russian Academy of Science, Schmidt Institute of Physics of the Earth, B. Gruzinskaya St. 10, 123995 Moscow, Russia. ${ }^{3}$ North Carolina Geological Survey, Coastal Plain Office and Core Repository, MSC 1620, Raleigh, NC 27699-1620, USA. ${ }^{4}$ Present address: Natural Hydrogen Energy Ltd, 819-35th Ave., Greeley, CO 80634, USA.

Received: 27 July 2015 Accepted: 29 September 2015

Published online: 09 October 2015

\section{References}

Abbott LE, Farrell KMJ, Nickerson JG, Gay NK. Lithic resources of the North Carolina Coastal Plain: prehistoric acquisition and utilization patterns. In: Ewen CR, Whyte TR, Davis RPSJ, editors. The archaeology of North Carolina: three archaeological symposia. North Carolina: North Carolina Archaeological Council Publication No. 30; 2011. p. 2-1-2-51. 
Apps JA, Van De Kamp PC. Energy gases of abiogenic origin in the Earth's crust. Futur Energy Gases United States Geol Surv Prof Pap. 1993; 81-130.

Battani A, Deville E, Faure JL, Jeandel E, Noirez S, Tocqué E et al (2010) Geochemical study of natural $\mathrm{CO}_{2}$ emissions in the French Massif Central: how to predict origin, processes and evolution of $\mathrm{CO}_{2}$ leakage. Oil Gas Sci Technol-Rev I'Institut Français du Pétrole 65:615-633. doi:10.2516/ogst/2009052

Bixio AC, Gambolati G, Paniconi C, Putti M, Shestopalov VM, Bublias VN et al (2002) Modeling groundwater-surface water interactions including effects of morphogenetic depressions in the Chernobyl exclusion zone. Environ Geol 42:162-177. doi:10.1007/s00254-001-0486-7

Bonini M (2012) Mud volcanoes: indicators of stress orientation and tectonic controls. Earth Sci Rev 115(3):121-152. doi:10.1016/j.earscirev.2012.09.002

Brooks MJ, Taylor BE, Ivester AH (2010) Carolina Bays: time capsules of culture and climate change. Southeast Archaeol 29:146-163

Brown PM. Geological map of North Carolina. Department of Natural Resources and Community Development of North Carolina. 1985.

Brown PM, Miller JA, Swain FM. Structural and stratigraphic framework and spatial distribution of the permeability of the Atlantic Coastal Plain, North Carolina to New York: US Geological Survey Professional Paper 796. 1972.

Butler JR. Review and classification of ultramafic bodies in the Piedmont of the Carolinas. In: Mittwede SK, Stoddard EF, editors. Ultramafic rocks of the Appalachian Piedmont. Geological Society of America Special Paper 231; 1989. p. 19-31.

Cohen AD, Gage CP, Moore WS, VanPelt RS (1999) Combining organic petrography and palynology to assess anthropogenic impacts on peatlands: part 2. An example from a Carolina Bay wetland at the Savannah River Site in South Carolina. Int J Coal Geol 39:47-95. doi:10.1016/S0166-5162(98)00040-8

Conrad R, Seiler W (1981) Decomposition of atmospheric hydrogen by soil microorganisms and soil enzymes. Soil Biol Biochem 13:43-49. doi:10.1016/0038-0717(81)90101-2

Cussler EL (2009) Diffusion mass transfer in fluid systems, 3rd edition. University Press, Cambridge

Das B (2008) Advanced soil mechanics. Taylor \& Francis, London \& New York

Eyton JR, Parkhurst JI. A re-evaluation of the extraterrestrial origin of the Carolina Bays. Geography Graduate Student Association, University of Illinois at Urbana-Champaign. 1975, 92 p.

Farrell KM, Harris WB, Mallinson DJ, Culver SJ, Riggs SR, Pierson J et al (2012) Standardizing texture and facies codes for a process-based classification of clastic sediment and rock. J Sediment Res 82:364-378. doi:10.2110/jsr.2012.30

Farrell KM, Harris WB, Mallinson DJ, Culver SJ, Riggs SR, Wehmiller JF et al (2013) Graphic logging for interpreting process-generated stratigraphic sequences and aquifer/reservoir potential: with analog shelf to shoreface examples from the Atlantic Coastal Plain Province, USA. J Sediment Res 83:723-745. doi:10.2110/ jsr.2013.52

Firstov PP, Shirokov VA (2005) Dynamics of molecular hydrogen and its relation to deformational processes at the Petropavlovsk-Kamchatskii geodynamic test rite: evidence from observations in 1999-2003. Geochemistry Int 43:1056-1064

Folkerts GW (1997) Citronelle ponds: little-known wetlands of the Central Gulf Coastal Plain, USA. Nat Areas J 17:6-16

Freund F, Dickinson JT, Cash M (2002) Hydrogen in rocks: an energy source for deep microbial communities. Astrobiology 2:83-92. doi:10.1089/153110702753621367

Frey DG (1954) Evidence for the recent enlargement of the "bay" lakes of North Carolina. Ecology 35:78. doi:10.2307/1931408

Garcia B, Billiot JH, Rouchon V, Mouronval G, Lescanne M, Lachet V et al (2012) A geochemical approach for monitoring a $\mathrm{CO}_{2}$ pilot site: Rousse, France. A major gases, CO2 -carbon isotopes and noble gases combined approach. Oil Gas Sci Technol - Rev d'IFP Energies Nouv 67:341-353. doi:10.2516/ogst/ 2011154

Grant JA, Brooks MJ, Taylor BE (1998) New constraints on the evolution of Carolina Bays from ground-penetrating radar. Geomorphology 22:325-345. doi:10.1016/S0169-555X(97)00074-3

Hough B (1969) Basic soil engineering. Ronald Press Company, New York

Isaev El, Skorodumova NV, Ahuja R, Vekilov YK, Johansson B (2007) Dynamical stability of Fe-H in the Earth's mantle and core regions. Proc Natl Acad Sci U S A 104:9168-71. doi:10.1073/pnas.0609701104

Ivester AH, Godfrey-Smith DI, Brooks MJ, Taylor BE. The timing of Carolina Bay and inland activity on the Atlantic coastal plain of Georgia and South Carolina. In: Geological Society of America. Denver Annual Meeting. Geological Society of America; 2004. p 69
Jones VT, Pirkle RJ (1981) Helium and hydrogen soil gas anomalies associated with deep or active faults. 181st ACS National Meeting, Atlanta, GA

Kite LE (1982) The Halifax County complex: oceanic lithosphere in the northeastern Piedmont, North Carolina. North Carolina State University, Raleigh, NC

Kite LE, Stoddard EF (1984) The Halifax County complex: oceanic lithosphere in the eastern North Carolina Piedmont. Bull Geol Soc Am 95:422-432. doi:10.1130/0016-7606(1984)95<422:THCCOL>2.0.CO;2

Larin VN, Warren Hunt C. Hydridic Earth: the new geology of our primordially hydrogen-rich planet. Alberta: Polar Publishing; 1993.

Larin NV, Zgonnik V, Rodina S, Deville E, Prinzhofer A, Larin VN. (2014) Natural molecular hydrogen seepage associated with surficial, rounded depressions on the European craton in Russia. Nat Resour Res 24(3):369-383. doi:10.1007/s11053-014-9257-5

Lawrence DP, Hoffman CW, Geology of basement rocks beneath the North Carolina Coastal Plain. North Carolina Geological Survey Bulletin 95. 1993.

Lin L-H, Hall J, Lippmann-Pipke J, Ward JA, Sherwood Lollar B, DeFlaun M, et al (2005) Radiolytic $\mathrm{H}_{2}$ in continental crust: nuclear power for deep subsurface microbial communities. Geochemistry Geophys Geosystems 6:1-13. doi:10.1029/2004GC000907

McCarthy H, McGuire E. Soil gas studies along the Carlin trend, Eureka and Elko counties, Nevada. In: Tosdal RM, editor. Contributions to the gold metallogeny of Northern Nevada. Open-File Report 98-338 1998. US Dept. of the Interior, US Geological Survey, Menlo Park; 1998. pp 243250

Moore CR, Brooks MJ, Mallinson DJ, Parham PR, Mester AH, Feathers JK. (2014) Rapid scour, sand rim construction, and basin migration of a Carolina Bay in Southeastern North Carolina. Geological Society of America, Abstracts with Programs V 46(3):96

Nealson KH, Inagaki F, Takai K (2005) Hydrogen-driven subsurface lithoautotrophic microbial ecosystems (SLiMEs): do they exist and why should we care? Trends Microbiol 13:405-10. doi:10.1016/j.tim.2005.07.010

Ohmoto H (1997) When did the Earth's atmosphere become toxic. Geochemical News 93(12-13):26-27

Polyanskaya LV, Sukhanova NI, Chakmazyan KV, Zvyagintsev DG (2014) Specific features of the structure of microbial biomass in soils of annular mesodepressions in Lipetsk and Volgograd oblasts. Eurasian Soil Sci 47:904-909. doi:10.1134/S1064229314090105

Prouty WF (1952) Carolina bays and their origin. Bull Geol Soc Am 63:167-224. doi:10.1130/0016-7606(1952)63

Rogozhin EA, Gorbatikov AV, Larin NV, Stepanova MY (2010) Deep structure of the Moscow Aulacogene in the western part of Moscow. Izv Atmos Ocean Phys 46:973-981. doi:10.1134/S0001433810080062

Ross TE (1987) A comprehensive bibliography of the Carolina bays literature. J Elisha Mitchell Sci Soc 103:28-42

Sato M, Sutton AJ, McGee KA, Russell-Robinson S (1986) Monitoring of hydrogen along the San Andreas and Calaveras Faults in central California in 1980-1984.

J Geophys Res 91:12315-12326. doi:10.1029/JB091iB12p12315

Savchenko VP (1958) The formation of free hydrogen in the Earth's crust as determined by the reducing action of the products of radioactive transformations of isotopes. Geochemistry Int 1:16-25

Semlitsch RD (2000) Size does matter: the value of small isolated wetlands. Natl Wetl Newsl 22:5-6

Shcherbakov AV, Kozlova ND (1986) Occurrence of hydrogen in subsurface fluids and the relationship of anomalous concentrations to deep faults in the USSR. Geotectonics 20:120-128

Sherwood Lollar B, Onstott TC, Lacrampe-Couloume G, Ballentine CJ (2014) The contribution of the Precambrian continental lithosphere to global $\mathrm{H}_{2}$ production. Nature 516:379-382. doi:10.1038/nature14017

Smith NJP, Shepherd TJ, Styles MT, Williams GM (2005) Hydrogen exploration: a review of global hydrogen accumulations and implications for prospective areas in NW Europe, Petroleum Geology: North-West Europe and Global Perspectives_-Proceedings of the 6th Petroleum Geology Conference. Geological Society, London, pp 349-358

Stolt MH, Rabenhorst MC (1987) Carolina Bays on the eastern shore of Maryland: II. Distribution and origin. Soil Sci Soc Am J 51:399. doi:10.2136/sssaj1987 $.03615995005100020026 x$

Sugimoto A, Fujita N (2006) Hydrogen concentration and stable isotopic composition of methane in bubble gas observed in a natural wetland. Biogeochemistry 81:33-44. doi:10.1007/s10533-006-9028-4 
Sugisaki R, Ido M, Takeda H, Isobe Y, Hayashi Y, Nakamura N et al (1983) Origin of hydrogen and carbon dioxide in fault gases and its relation to fault activity. J Geol 91:239-258

Sukhanova NI, Trofimov SY, Polyanskaya LM, Larin NV, Larin VN. (2013) Changes in the humus status and the structure of the microbial biomass in hydrogen exhalation places. Eurasian Soil Sci 46:135-144. doi:10.1134/ S1064229313020142

Swiss Standard SN 670 010b. Characteristic coefficients of soils. Association of Swiss Road and Traffic Engineers, Zurich 1999.

Syvorotkin VL (2010) Hydrogen degassing of the Earth: natural disasters and the biosphere, Man and the Geosphere. Nova Science Publishers, New York, pp 307-347

Thom BG (1970) Carolina Bays in Horry and Marion Counties, South Carolina. Geol Soc Am Bull 81:783-814. doi:10.1130/0016-7606(1970)81[783:CBIHAM]2.0.CO;2

Toulhoat H, Beaumont V, Zgonnik V, Larin NV, Larin VN. Chemical differentiation of planets: a core issue. Submitted for publication. Available at: http:// arxiv.org/abs/1208.2909v2 (2015).

Wakita H, Nakamura Y, Kita I, Fujii N, Notsu K. (1980) Hydrogen release: new indicator of fault activity. Science 210:188-90. doi:10.1126/ science.210.4466.188

Ware $\mathrm{RH}$, Roecken C, Wyss M (1985) The detection and interpretation of hydrogen in fault gases. Pure Appl Geophys PAGEOPH 122:392-402. doi:10.1007/BF00874607

\section{Submit your manuscript to a SpringerOpen ${ }^{\circ}$ journal and benefit from:}

- Convenient online submission

- Rigorous peer review

- Immediate publication on acceptance

- Open access: articles freely available online

- High visibility within the field

- Retaining the copyright to your article

Submit your next manuscript at springeropen.com 